\title{
The Reaction of Groundwater to Several Months' Meteorological Drought in Poland
}

\author{
Justyna Kubicz ${ }^{1 *}$, Bogdan Bąk ${ }^{2}$ \\ ${ }^{1}$ Wroclaw University of Environmental and Life Sciences, Institute of Environmental Engineering, Wroclaw, Poland \\ ${ }^{2}$ Institute of Technology and Life Sciences, Kuyavian-Pomeranian Research Center, Bydgoszcz, Poland
}

Received: 6 June 2017

Accepted: 2 January 2018

\begin{abstract}
Our article presents the results of research aimed at determining the effect of precipitation on the level of the groundwater table and the impact of meteorological drought on the hydrogeological groundwater level in the area of Kujawy and Wielkopolska in the years 1981-2015. Monthly sums of precipitation came from Bydgoszcz and Poznan. Underground water table levels were measured by the Geological Institute in the area of Kujawy, near Bydgoszcz (Solec Kujawski and Jagodowo) and in the area of Wielkopolska (Stęszew and Czachurki). The drought periods were determined on the basis of standardized precipitation index (SPI), meteorology drought, and standardized groundwater level (SGI) in four time scales $(6,12$, 24, and 48 months).

The results confirmed the findings of other authors that there is no linear relationship between the terms of meteorological drought and hydrogeological groundwater drought. The relatively low value of correlation coefficients between SPI and SGI indices show that the groundwater droughts are affected by other factors independent of rainfall. The relationships between the climatic conditions and the level of the water table as well as groundwater droughts were determined by the properties of the aquifer.
\end{abstract}

Keywords: meteorological drought, groundwater drought, SPI, SGI, correlation

\section{Introduction}

In economic, social, and environmental terms drought is recognized as one of the most damaging natural disasters [1]. It is generally believed that climate change has caused a marked increase in the frequency of droughts in the northern hemisphere since the 1970s. The expansion of areas affected by this phenomenon for longer dry periods and an increase in their intensity are still being observed [2-4]. Problems with access to water sources are the cause of social conflicts, which intensified

*e-mail: justyna.kubicz@upwr.edu.pl especially in the early $21^{\text {st }}$ century [5-6]. Droughts cause problems mainly with access to surface water resources, generate losses in agriculture, and often contribute to irreversible changes in ecosystems dependent on water [7-8]. As other important effects of drought, a number of forest fires and increased mortality, especially in periods of heat waves, may be mentioned [9-10].

In literature there is no uniform definition of a drought, since there are different reasons for its formation [11]. Most often it is assumed that it is a period of significantly reduced precipitation, which results in restrictions on water accessibility [12-15]. In our latitudes, intensity of draught increases due to high temperature and increased evaporation [16-18]. 
An important and still little-known aspect of the impact of drought on the environment is the reaction of the groundwater to meteorological drought, especially in those areas where the drought is common. Diverse environmental geological conditions play an important role in these relationships. Wielkopolska and Kujawy are among the driest regions in Poland, as confirmed by several observations and studies carried out since the mid-19 ${ }^{\text {th }}$ century [19-25]. Meteorological droughts in these regions often appeared in the last two decades of the $20^{\text {th }}$ century and early $21^{\text {st }}$ century. Numerous scenarios of climate change foresee that they will also appear in the next decades in the first half of this century [26-28]. The drought in Wielkopolska in 1992 is an example of the impact of meteorological drought on groundwater. This caused a drastic reduction of the water level in Warta and the groundwater table in the water intake Mosina, near the agglomeration of Poznań. The drought also caused damage in a national park and Rogalin Landscape Park [29].

Monitoring hydrogeological conditions in Poland has beencarried outsince 2006 by the NationalHydrogeological Service within the framework of National Environmental Monitoring. Statistically processed monitoring data of the groundwater heads and spring rates are reported by the Quarterly Bulletin of Groundwater issued by Polish Geological Institute - National Research Institute. In parallel, National Water Management is also running a project titled "Developing plans to counter the effects of drought in river basin areas." Its main task is to propose mitigation and prevention measures to limit the negative impact of drought on society, the environment, and the economy [32]. In addition, the project collects evidence of the drought spells in Poland and identifies the regions particularly exposed to the appearance of drought.

Investigating the effect of meteorological drought on hydrogeological drought has already been conducted in the UK, the Netherlands, and some other countries. Currently, most of this type of research is carried out using the indicator method. In the national literature examples of work that examined, among others, the relationships between the meteorological drought [19, 36] and hydrological drought [37] can also be found. Standardized precipitation index (SPI) was used in the case of meteorological droughts, which were calculated on the basis of long-term (at least 30 years), rainfall in the case of most droughts, which is calculated on the basis of long-term, at least 30 year rainfall measurement sequences. In the case of hydrogeological drought the standardized groundwater level (SGI) that often appears in literature may be used [40-41]. In this case it is also recommended to use the longest possible measurements of the groundwater table. In the case of both droughts, SPI and SGI allow for the adoption of the same methodology of preparation measurement data, calculating the values of indicators and using the same classification of drought intensity, and setting the parameters of drought, like the beginning and end of an occurrence and its duration and intensity. The research concern regarding relationships between both droughts was carried out in different time scales of 1 to 48 months [42-43].

Research conducted by Bloomfield and Marchant [40] van Loon [1] and Kumar [43] in the area of Great Britain, Germany, and the Netherlands showed no linear relationship between current rainfall and the current level of the groundwater table. In some Asian regions often affected by meteorological drought, a significant correlation between rainfall and the level of groundwater table was found at the end of a 24-month meteorological drought [44]. These authors examining the relationship using indicators SPI and SGI accumulating periods of rainfall $(6,12,24$, and 48 months) and the average monthly water level showed a relationship between both droughts, and also a delayed reaction of the aquifer to the lack of precipitation.

The aim of the article was to determine the relationship between long-term meteorological drought and groundwater drought in the area of Wielkopolska and Kujawy. This goal was realized by indicator-based method and the results are explained by additional references to literature concerning the characteristics of precipitation and geological measurements in the studied locations. The knowledge gained will explain the response of groundwater to shortages of rainfall and may be useful in managing the intake of water during meteorological drought.

\section{Materials and Methods}

\section{Study Sites and Data}

Precipitation conditions in Kujawy and Wielkopolska were determined on the basis of monthly sums of precipitation $\mathrm{P}(\mathrm{mm})$ in a multi-year period (1981-2015) from the station belonging to the Institute of Meteorology and Water Management at the National Research Institute (IMGW-PIB) in Poznan, and the station belonging to the Institute of Technology and Life Sciences (ITP) in Bydgoszcz. Groundwater levels were measured at four piezometric wells belonging to the observational research of Polish Geological Institute-National Research Institute (PGI-PIB). In Kujawy, measuring points were located in Solec Kujawski and Jagodowo near Bydgoszcz, in Wielkopolska Lowland in Stęszew and Czachurki near Poznan (Fig. 1). For analysis and calculation, average monthly values of the position of the groundwater level $\mathrm{H}$ (m) were used.

Although measurements of water level in Jagodowo and Solec Kujawski started at the turn of 1976 and 1977, due to periodic shortages of the analysis of sequences of measurements reported in multi-years, we used 1992-2015 and 1980-2015. In the case of Stęszew and Czachurki, the measuring period covered the years 1980-2015.

The measurement points are located on the Polish Lowland. The point in Solec Kujawski is located within the Torun Basin, in Jagodowo, in Wysoczyzna Świecka, an upland, and in Stęszew it is located on the Poznan 


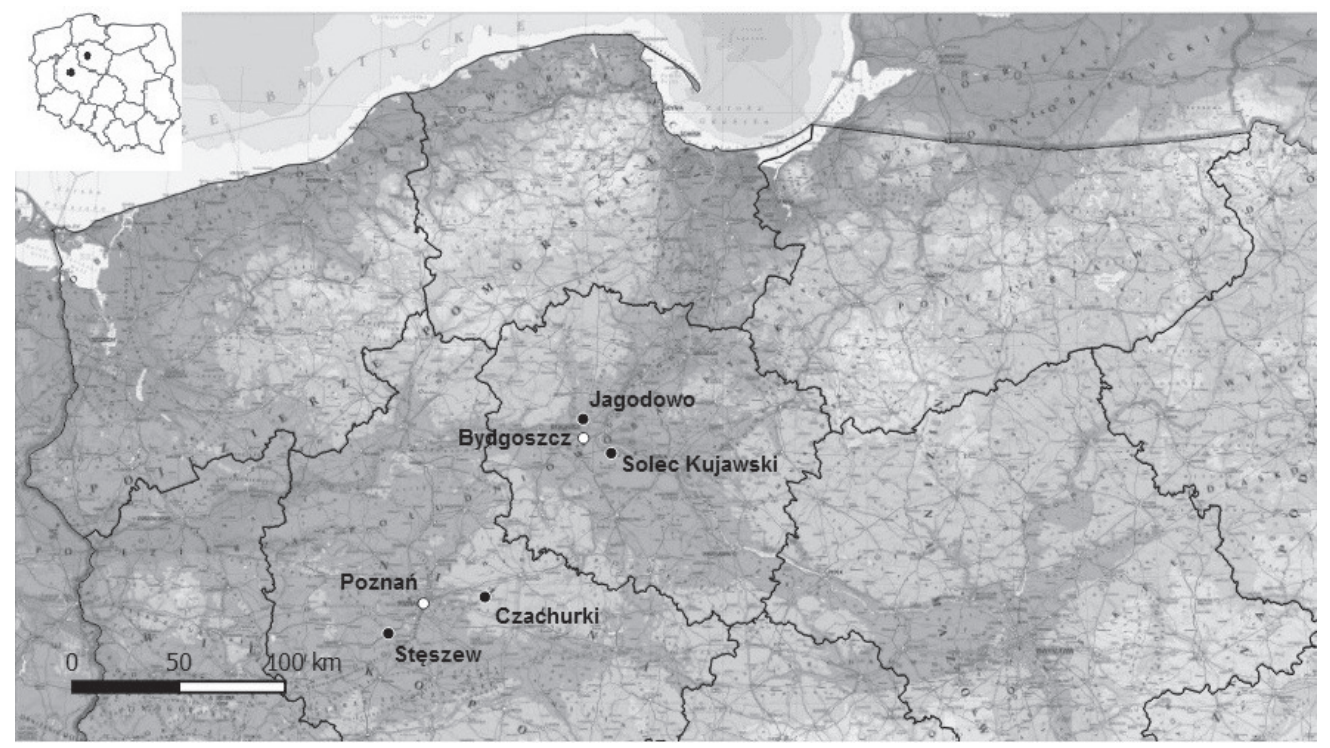

Fig. 1. Location of piezometric wells and meteorological stations.

Lakeland Area and Gniezno in Czachurki Lakeland [4547]. In terms of hydrogeological measuring, the stations in Stęszew and Czachurki are located in the basin of the Warta River, in the lowland subregion, and in Solec Kujawski and Jagodowo located in the basin of the lower Vistula River in the lakeland subregion [48].

Measured aquifers occurred in deposits of quaternary, in sands, and sand with gravel [49]. Water surfaces at all points have changed periodically, which was caused by the water flows and hydrometeorological factors [49-51]. In particular places according to geological data different thicknesses of aquifer were found: Stęszew (II/406/1)
3.8 m, Czachurki (I/428/4) 7.7 m, Solec Kujawski (II/185/1) $13 \mathrm{~m}$, and Jagodno (I/257/4) about $68 \mathrm{~m}$. Three observation points are located in the area of main groundwater basins (MGBs). The exception was in Solec Kujawski. In addition, the location of water intakes may have an impact on the position of the groundwater levels in these points. This factor should be taken into account in the case of the observation in Czachurki. The monitoring point $\mathrm{I} / 428 / 4$ in Czachurki is located in the influence zone of two underground water intakes for Poznan and Gniezno. Collective information on measuring points is presented in Table 1.

Table 1. Summary of analyzed information about the monitoring points (source: own study).

\begin{tabular}{|c|c|c|c|c|}
\hline Point number & II/185/1 & $\mathrm{I} / 257 / 4$ & II/406/1 & $\mathrm{I} / 428 / 4$ \\
\hline Site & Solec Kujawski & Jagodowo & Stęszew & Czachurki \\
\hline Stratygraphy & Quaternary & Quaternary & Quaternary & Quaternary \\
\hline Lithology & Sands & Sands & Sands and gravels & Sands and gravels \\
\hline Start of records & 1985 & 1992 & 1980 & 1980 \\
\hline End of records & 2015 & 2015 & 2015 & 2015 \\
\hline $\begin{array}{l}\text { Mean annual precipitation }(\mathrm{mm}) \\
\text { meteorological stations }\end{array}$ & \multicolumn{2}{|c|}{$\begin{array}{c}513 \\
\text { Bydgoszcz }\end{array}$} & \multicolumn{2}{|c|}{$\begin{array}{c}526 \\
\text { Poznań }\end{array}$} \\
\hline \multirow{3}{*}{$\begin{array}{l}\text { Groundwater level } \\
\text { (m a.s.1.) }\end{array}$} & Min & 41.6 & 76.3 & 85.9 \\
\hline & Max & 41.7 & 78 & 87.5 \\
\hline & Mean & 42.4 & 77.2 & 86.4 \\
\hline Well depth relative to soil surface (m) & 14 & 71.5 & 8.1 & 8.5 \\
\hline Water table met during drilling (m) & 1.0 & 2.72 & 4.72 & 0.8 \\
\hline $\begin{array}{l}\text { Average hydraulic conductivity of aquifer } \\
\qquad\left(\mathrm{m} \cdot \mathrm{s}^{-1}\right)\end{array}$ & $3 \cdot 10^{-4} \div 1 \cdot 10^{-4}$ & $3 \cdot 10^{-4} \div 1 \cdot 10^{-4}$ & $3 \cdot 10^{-4} \div 1 \cdot 10^{-4}$ & $3 \cdot 10^{-4} \div 1 \cdot 10^{-4}$ \\
\hline Surface features & $\begin{array}{l}\text { Soils comprising } \\
\text { loose sand and } \\
\text { loamy sand }\end{array}$ & $\begin{array}{l}\text { Soils comprising } \\
\text { loamy loose sand }\end{array}$ & $\begin{array}{l}\text { Soils comprising } \\
\text { glacial tills and } \\
\text { sands overlying } \\
\text { loam or silt } \\
\end{array}$ & $\begin{array}{l}\text { Soils comprising } \\
\text { loose sand }\end{array}$ \\
\hline Major groundwater basin (MGB) & - & 140 & 144 & 144 \\
\hline
\end{tabular}




\section{Research Method}

This paper uses an indicator-based method that allows for adopting the same methodology of calculating values of the meteorological and hydrogeological drought, determining the parameters of drought, and adopting the same classification of drought intensity [52-53]. SPI is quoted widely in the literature for meteorological drought $[11,26,28,38,43,54-64]$. Despite the objections of some authors who drew attention to the possible restriction of the use of this indicator [41], it is recommended by the World Meteorological Organization (WMO) to monitor the operating risk of drought [65].

A standardized rate of the groundwater-level SGI (standardized groundwater level index) was chosen as a hydrological drought index used in this paper. It is calculated based on the measuring of ground water level $\mathrm{H}[41,44]$. SGI is a rate equivalent to the rate of SWI, which was proposed by Bhuiyan [39] and is also used to monitor groundwater shortages.

The values of indicators are the standardized deviations of precipitation and groundwater levels from the median value in the multi-year studied period. In Kujawy and Wielkopolska it has practically been verified earlier by Łabędzki [54]. The good fit to a normal distribution of strings of homogenous precipitation was obtained by transforming function $\mathrm{f}(\mathrm{P})=\sqrt[3]{x}$ [54]. As a hydrological factor, which is also recommended in the literature, a two-parameter logarithmic function $\mathrm{ln}$ was adopted [66-67]. Compatibility of the transformed variable distribution $\mathrm{f}(\mathrm{P})$ with the normal distribution should be examined using, e.g., Pearson's chi-squared test or the Kolmogorov-Smirnov test. The positive test result enables further calculation of the values SPI and CGI according to the equation:

$$
Z=\frac{f(X)-\hat{\mu}}{\hat{\delta}}
$$

...where $Z$ is choosen index (SPI, $S W I), P$ is precipitation [mm], $H$ is water level [m], $f(X)$ is transformer sums of precipitation or water level, $\hat{\mu}$ is mean of normalized $X$, and $\hat{\delta}$ is standard deviation of normalized $X$.

According to McKee [68], it has been assumed that in times of drought all the values of SPI and SGI are negative, while at least in one month, these values are lower than or equal to -1.0. The interruption of drought occurs when the value of the indices increases to zero. For the indices whose values satisfy the condition $X<-1.0$, a joint assessment by three classes of intensive drought was adopted [37]. Thresholds of -1.0 are responsible for moderate drought, -1.5 for severe drought, and -2.0 for extreme drought.

Studies of meteorological and hydrological droughts were carried out in time scales of $6,12,24$, and 48 months. An important aim of our work was to determine the relationships between the two droughts based on the correlation coefficients $r$ between SPI and SGI [52, 62] and the relationship between SPI and the monthly average of the groundwater level $\mathrm{H}$. The small value of $r$ is not indicative of a total lack of relationship between
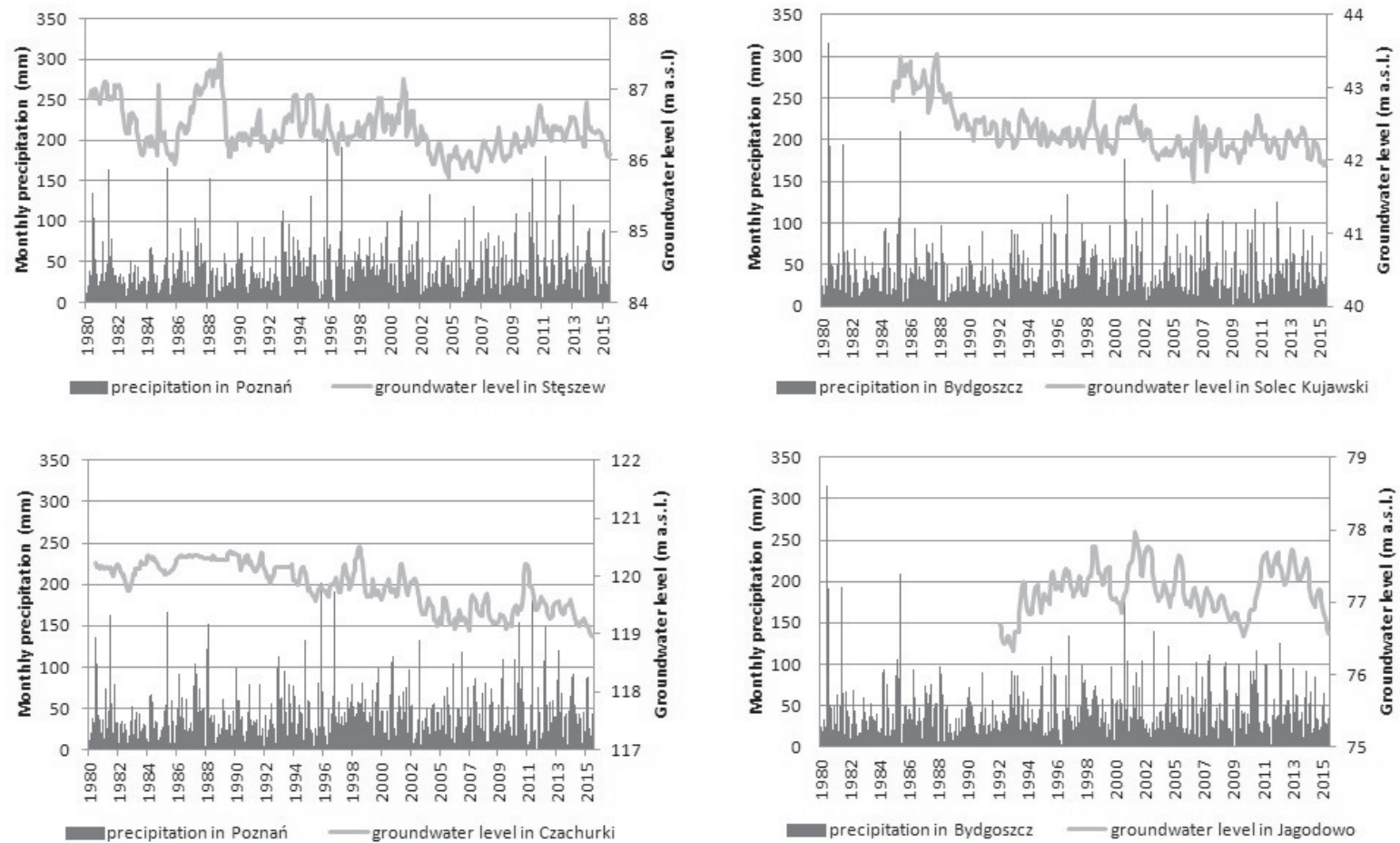

Fig. 2. Monthly sums of precipitation P ( $\mathrm{mm}$ ) corresponding with mean monthly groundwater level $\mathrm{H}(\mathrm{m})$ for the study sites (source: own study). 
droughts, but it indicates a much larger share of other external factors that weaken these relationships. Greater values are evidence of the increased rainfall infiltration capability by the aquifer. The appropriate classification of assessment depending on the value of $r$ was presented by Bachmair et al. [69]. Additionally, it was checked how the value of the correlation coefficients were changed taking into account the time shift of meteorological drought in relation to groundwater drought, and a reaction of water levels and the mutual relationships of the two types of drought [70].

\section{Results and Discussion}

The variability of mean monthly values of the ground water table $\mathrm{H}$ and simultaneous precipitation $\mathrm{P}$ is shown in Fig. 2.

In the analyzed multi-year period in Poznan (8 years) and in Bydgoszcz (16 years) we observed annual rainfall lower than the long-term average. Furthermore, a number of a few months' sequences of significantly lower rainfall than the long-term average were noted. In Poznan there were 11 and in Bydgoszcz 13 of such periods of rainfall deficiency. The longest periods with a series of dry months occurred in both towns in the multi-year period from 1982 to 1985 and in 2015. In other years, e.g., 1989, 1992, 2004, 2006, 2008, and 2015 we found a series of at least four-month periods of reduced rainfall. Reaction levels of groundwater to the shortage of rainfall were analyzed at measuring points. Lowering the water level frequently appeared with a delay, e.g., in Stęszew in response to the drought in the period from
Table 2. Correlation coefficients $r$ between monthly SPI and monthly average groundwater table $\mathrm{H}(\mathrm{m})$ (source: own study).

\begin{tabular}{|c|c|c|c|c|}
\hline \multirow{2}{*}{ Site } & \multicolumn{4}{|c|}{$r$} \\
\cline { 2 - 5 } & SPI-6 & SPI-12 & SPI-24 & SPI-48 \\
\hline Solec Kujawski & $0.22^{*}$ & $0.25^{*}$ & $0.16^{*}$ & $-0.16^{*}$ \\
\hline Jagodno & -0.02 & 0.04 & -0.02 & -0.00 \\
\hline Czachurki & -0.02 & $-0.10^{*}$ & $-0.20^{*}$ & $-0.32^{*}$ \\
\hline Stęszew & $0.26^{*}$ & $0.35^{*}$ & $0.41^{*}$ & $0.24^{*}$ \\
\hline
\end{tabular}

*statistical significance at the 0.05 level

1982 to 1986 it was observed between 1985 and 1986 . In Jagodno the drought occurred in 2006 and 2008, and its effects appeared in 2009 and 2010. Examples of simultaneous courses of meteorological and hydrological drought were determined on the basis of SPI and SGI (Fig. 3). Values of the correlation between coefficient SPI and groundwater level $\mathrm{H}$ are shown in Table 2. In most cases, these relationships were statistically significant at the 0.05 level.

The best relationships were found in Stęszew (SPI-24 vs. $\mathrm{H}, \mathrm{r}=0.41$ ) and Czachurki (SPI-48 vs. $\mathrm{H}, \mathrm{r}=-0.32$ ). The results indicate the fact that these relationships were determined by the properties of the surface layer, which delayed the flow of rain to the water-bearing system. It was found that in more concise soils in Stęszew this delay was longer than in light soils in Solec Kujawski. However, in Jagodno due to the thickness of the aquifer (over $71 \mathrm{~m}$ ), there was no effect of precipitation conditions on water level. Demonstrated lack of association between
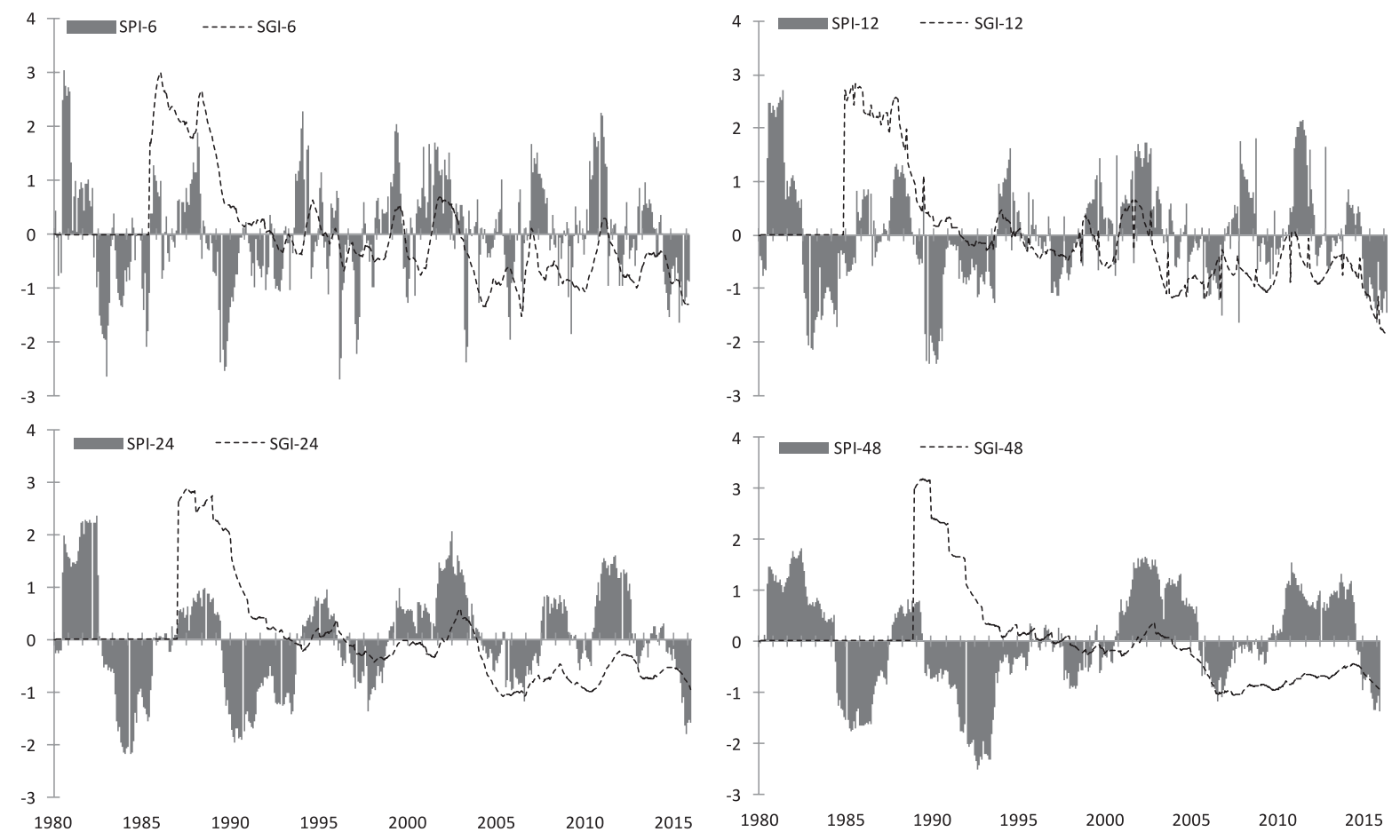

Fig. 3. Example plots of SPI and SGI in different time series for Bydgoszcz and Solec Kujawski (source: own study). 
Table 3. Correlation coefficients between SPI and groundwater H in different scales of time delay (source: own study).

\begin{tabular}{|c|c|c|c|c|c|c|c|c|c|c|c|c|}
\hline \multirow{2}{*}{ SPI } & \multirow{2}{*}{ Site } & \multicolumn{8}{|c|}{ Time delay (months) } & \multicolumn{1}{|c|}{} \\
\cline { 3 - 13 } & & 1 & 2 & 3 & 4 & 5 & 6 & 9 & 12 & 18 & 24 & 48 \\
\hline SPI-12 & Solec Kujawski & $0.25^{*}$ & $0.22^{*}$ & $0.19^{*}$ & $0.17^{*}$ & $0.16^{*}$ & $0.12^{*}$ & $-0.12^{*}$ & $-0.25^{*}$ & $-0.38^{*}$ & $-0.38^{*}$ & $-0.42^{*}$ \\
\hline SPI-48 & Czachurki & $-0.30^{*}$ & $-0.30^{*}$ & $-0.30^{*}$ & $-0.31^{*}$ & $-0.31^{*}$ & $-0.31^{*}$ & $-0.31^{*}$ & $-0.31^{*}$ & $-0.30^{*}$ & $-0.28^{*}$ & $-0.37^{*}$ \\
\hline SPI-24 & Stęszew & $0.45^{*}$ & $0.45^{*}$ & $0.45^{*}$ & $0.44^{*}$ & $0.42^{*}$ & $0.40^{*}$ & $0.32 *$ & $0.25 *$ & 0.09 & $-0.15^{*}$ & $-0.50^{*}$ \\
\hline
\end{tabular}

* Statistical significance at the 0.05 level

SPI and $\mathrm{H}$ in this location was the reason why further research in Jagodno has been discontinued. The negative relationship between the indicators SPI-12, SPI -24, and SPI -48 and the mean level of the groundwater table $\mathrm{H}$ was observed in Czachurki. The absolute values of these correlation coefficients were increased with the length of accumulating time. The probable cause of the reverse relationships, especially in increased periods of rainfall deficiency, was the water consumption for Poznan and Gniezno from MGBs.

The study assuming that the impact of rainfall on the water table may appear with a delay of some months, of from 1 to 48. The results obtained in Stęszew, Czachurki, and Solec Kujawski have shown that these relationships were varied (Table 3). In the case of Stęszew it showed that if the interactions were to occur they would be the strongest in months 1-6 or 48, whereas in Czachurki their relationships were reversed and they would be almost constant. Interesting results were obtained in Solec Kujawski, where a positive and at the same time a weakening relationship occurred during months 1-6. Delay would cause a reversal of these relationships, the value of the correlation coefficient would be negative, and the absolute value of the calculated correlation coefficients increase.

The next stage of the study was assessing the relationships between SGI and SPI for different periods of time (Table 4). In this part of the analysis the results of previous analyses were taken into account. The best correlated SPI with groundwater level H (Table 3) were correlated with SGI (Table 4).

The best relationship between SPI-24 and SGI- 6 was found in Stęszew, the SPI-48 and the SGI-48 in Czachurki and SPI-12 and SGI-48 in Solec Kujawski (Table 5). The

Table 4. Correlation coefficients $r$ in selected periods of time between SPI and SGI (source: own study).

\begin{tabular}{|c|c|c|c|c|c|}
\hline \multirow{2}{*}{ SPI } & \multirow{2}{*}{ site } & \multicolumn{3}{|c|}{$r$} \\
\cline { 3 - 6 } & & SGI-6 & SGI-12 & SGI-24 & SGI-48 \\
\hline SPI-12 & $\begin{array}{c}\text { Solec } \\
\text { Kujawski }\end{array}$ & $0.13^{*}$ & $0.20^{*}$ & $-0.26^{*}$ & $-0.36^{*}$ \\
\hline SPI-48 & Czachurki & $-0.27 *$ & $-0.29 *$ & $-0.31 *$ & $-0.36^{*}$ \\
\hline SPI-24 & Stęszew & $0.51 *$ & $0.44 *$ & $-0.11 *$ & $-0.45^{*}$ \\
\hline
\end{tabular}

* Statistical significance at the 0.05 level relatively low value of the relationships between SPI and SGI points to the fact that the existence of hydrological drought is affected by other factors independent of rainfall. These include the physical properties of the terrain, the hydraulic properties of the aquifer [72-73], and anthropogenic factors [74].

The above relationships were also examined, assuming that the effects of SPI on SGI may increase with the delay in the selected months from 1 to 48 . The results obtained in Stęszew, Czachurki, and Solec Kujawskim showed SPI delay vs. SGI only in Czachurki (Table 5). The highest correlation coefficient was observed for four months of delay. The observation in this place suggested that a delay longer than four months caused weaker relationships. The delay between meteorological and groundwater drought in Stęszew caused a decrease in the absolute value correlation coefficients in months 1-18, and a slight increase in 24- and 48- months. The results obtained in Solec Kujawski indicated no connections between SPI and delay time in most cases.

Obtained results confirm findings of other authors, e.g., Bloomfield and Marchant [39] and van Loon [1], who signaled the lack of a linear relationship between meteorological drought and groundwater drought because usually both droughts are delayed. Research by Khan et al. [71] suggested that relationships between SPI and the level of groundwater $\mathrm{H}$ depend primarily on location in the hydrodynamic system, rainfall shortages, and groundwater exploitation accounting for economic purposes, in this case for irrigation of fields. Similar conclusions can be found in the work by Bhiiyan et al. and other works [39]. Research conducted in Iran by Mohammadi Ghaleni and Ebrahimi [44] and Chamanpira et al. [70] showed that after two years of meteorological drought, groundwater resources significantly decreased, and a shift of both droughts on average was 12 months. As a reason for the delayed reaction of hydrological drought to meteorological drought, authors pointed out the properties of a geological formation, which in this case resulted in prolongation of infiltration of rainwater into the water-bearing system. It should be recalled that the level of groundwater is formed by a number of factors, including the physical properties of the terrain, the hydraulic properties of the aquifer, and changing weather conditions [72-73]. Whittemore [74] also noted that the anthropogenic impact, e.g., large consumption of water, could weaken the relationship between the level of groundwater and climate variables. 
Table 5. Correlation coefficients between SPI and SGI in selected time scales (in different scale delay) (source: own study).

\begin{tabular}{|c|c|c|c|c|c|c|c|c|c|c|c|c|}
\hline \multirow{2}{*}{$r$} & \multirow{2}{*}{ Site } & \multicolumn{10}{|c|}{ Time delay (months) } & \multirow[b]{2}{*}{48} \\
\hline & & 1 & 2 & 3 & 4 & 5 & 6 & 9 & 12 & 18 & 24 & \\
\hline $\begin{array}{c}\text { SPI-12 } \\
\text { vs. SGI-12 }\end{array}$ & $\begin{array}{c}\text { Solec } \\
\text { Kujawski }\end{array}$ & 0.02 & -0.01 & -0.03 & -0.06 & -0.08 & -0.10 & $-0.14 *$ & $-0.16^{*}$ & $-0.13^{*}$ & -0.06 & -0.02 \\
\hline $\begin{array}{c}\text { SPI-48 } \\
\text { vs. SGI-48 }\end{array}$ & Czachurki & $-0.30 *$ & $-0.33 *$ & $-0.33 *$ & $-0.38 *$ & $-0.33^{*}$ & $-0.32 *$ & $-0.32 *$ & $-0.31^{*}$ & $-0.31 *$ & $-0.29 *$ & $-0.23 *$ \\
\hline $\begin{array}{c}\text { SPI-24 } \\
\text { vs. SGI-6 }\end{array}$ & Stęszew & $0.48^{*}$ & $0.47^{*}$ & $0.44 *$ & $0.42 *$ & $0.39 *$ & $0.36^{*}$ & $0.27 *$ & $0.18^{*}$ & -0.06 & $-0.21 *$ & $0.55^{*}$ \\
\hline
\end{tabular}

* Statistical significance at the 0.05 level

\section{Conclusions}

Understanding the impact of long-term meteorological drought on changes in groundwater level and on the course of groundwater drought is a significant problem, especially in these regions where limited water resources are used for consumption and economic purposes. This problem is less frequently presented in the literature than the results of research regarding the relationships between meteorological drought and hydrological drought of surface waters. One of the reasons for this approach is the fact that water for the above-mentioned purposes is mainly taken from rivers and lakes, and in these places the changes of water resources caused by insufficient amount of precipitation are observed at the earliest. In arid agricultural regions, such as Wielkopolska and Kujawy regions, we observed an increase of the number of sprinklers that require the supply of water for agricultural production. In most cases it is groundwater. Water consumers, including farmers, are not always aware that after a long-time meteorological drought, there is a risk of delay, and groundwater drought and water consumption may be limited.

Important factors that should always be considered in researching the relationship between both droughts are the long-term local precipitation statistics and historical changes, the type and properties of the layer located directly above the aquifer, and the anthropogenic factors that influence these relationships. We must also remember that the environment is not a permanent element and that it can change as a result of the activities of nature and people.

\section{Acknowledgements}

The research was carried out with the statutory activity funds of the Faculty of Environmental Engineering and Geodesy, Wroclaw University of Environmental and Life Sciences in 2017, with agreement number B030/0102/17.

\section{References}

1. VAN LOON A.F., LAAHA G. Hydrological drought severity explained by climate and catchment characteristics. Journal of Hydrology 526, 3, 2015.
2. BLUNDEN J., ARNDT D., BARINGER M. State of the Climate in 2010. Bulletin of the American Meteorological Society 92 (6), 2011.

3. BURKE E.J., BROWN S.J., CHRISTIDIS N. Modeling the recent evolution of global drought and projections for the twenty-first century with the Hadley Centre climate model. Journal of Hydrometeorology 7 (5), 1113, 2006.

4. BOCZOŃ A., KOWALSKA A., DUDZIŃSKA M., WRÓBEL M. Drought in Polish Forests in 2015. Polish Journal of Environmental Studies 25 (5), 1857, 2016.

5. GARCIA-HERRERA R., DAZ J., TRIGO R.M., LUTERBACHERJ., FISCHER E.M. A review of the european summer heat wave of 2003. Critical Reviews in Environmental Science and Technology 40 (4), 267, 2010.

6. HSIANG S.M., BURKEM, MIGUEL E. Quantifying the influence of climate on human conflict. Science 341, 1235367-1, 2013.

7. LAKE P.S. X Drought and Aquatic Ecosystems: Effects and Responses. John Wiley \& Sons, 2011.

8. LEWIS S.L., BRANDO P.M., PHILLIPS O.L., VAN DER HEIJDEN G.M.F., NEPSTAD D. The 2010 Amazon drought. Science 331, 554, 2011.

9. WHILHITE D.A. Drought as a natural hazard: Concepts and definitions. Drought: A Global Assessment 3-18, 2000.

10. CARROLL N., FRIJTERS P., SHIELDS M.A. Quantifying the costs of drought: new evidence from life satisfaction data. Journal of Population Economics 22 (2), 445, 2009.

11. HAYES M., SVOBODA M., WALL N., WIDHALM M. The Lincoln declaration on drought indices: universal meteorological drought index recommended, Bulletin of the American Meteorological Society 92 (4), 485, 2010.

12. WHILHITE D.A., GLANTZ M.H. Understanding the drought phenomenon: the role of definitions. Water International 10 (3), 111, 1985.

13. WHILHITE D.A. Drought: A Global Assessment, vols. I \& II. Routledge Hazards and Disasters Series, Routledge, London, 2000.

14. TALLAKSEN L.M., VAN LANEN H.A.J. Hydrological drought: processes and estimation methods for streamflow and groundwater. Developments in Water Science 48, The Elsevier Science B.V., 2004.

15. MISHRA A.K., SINGH V.P. A review of drought concepts. Journal of Hydrology 391 (1-2), 202, 2010.

16. LEHNER B., DOELL P., ALCAMO J. Estimating the impact of global change on flood and drought risks in Europe: A continental, integrated assesment. Climatic Change 75, 273, 2006.

17. FEYEN L., DANKERS R. Impact of global warming on streamflow drought in Europe. Journal of Geophysical Research-Atmospheres 114, 2009. 
18. VAN LOON A.F. Hydrological drought explained, Wiley Interdisciplinary Reviews: Water 2 (4), 359, 2015.

19. ŁABĘDZKI L., BĄK B., KANECKA-GESZKE E., KASPERSKA-WOEOWICZ W., SMARZYŃSKA K. Relationship beetwen meteorological and agricultural drought in different agroclimatic regions in Poland. WodaŚrodowisko-Obszary Wiejskie - Rozprawy naukowe i monografie - 25, ITP, 2008.

20. BĄK B. Climatic conditions of Wielkopolska and Kujawy. Woda-Środowisko-Obszary Wiejskie 9, 14, 2004.

21. WOŚ A. Klimat Niziny Wielkopolskiej. Wydawnictwo Naukowe UAM w Poznaniu. Poznań, 1994 [In Polish].

22. WOŚ A. Klimat regionu środkowowielkopolskiego w świetle częstości występowania wybranych typów pogody i ich zmienności w latach 1951-2000. W: Józef Banaszak (red.) Stepowienie Wielkopolski pół wieku później. Wydawnictwo Akademii Bydgoskiej. Bydgoszcz, 2003 [In Polish].

23. ILNICKI P., FARAT R., GORECKI K., LEWANDOWSKI P. Impact of climatic change on River discharge in the driest region of Poland. Hydrological Sciences Journal. 59 (5-6), 1117, 2014

24. ŁABEDZKI L., BAK B. Differentiation of the atmospheric drought index SPI in the vegetation period in Poland. Woda-Środowisko-Obszary Wiejskie 4, 2a (11), 111,2004

25. MRUGAŁA S. Opady atmosferyczne o normalnej i anomalnej wysokości na obszarze Polski (1951-1990). Wydawnictwo UMCS. Rozpr. Habil. LXVI, 2001 [In Polish].

26. BĄK B., ŁABĘDZKI L. Prediction of precipitation deficit and excess in Bydgoszcz Region in view of predicted climate change. Journal of Water and Land Development 23 (X-XII), 11, 2014.

27. BARTCZAK A., GLAZIK R., TYSZKOWSKI S. Identification and evaluation of the intensity of dry periods in eastern part of Kujawy. Nauka Przyroda Technologie 8, 4, 46, 2014.

28. BORDI I., FRAEDRICH K., SUTERA A. Observed drought and wetness trends in Europe: an update. Hydrology and Earth System Sciences 13, 1519, 2009.

29. GORSKI J., PRZYBYŁEK J. Wpływ suszy w latach 19891992 na warunki eksploatacji infiltracyjnych ujęć wody w dolinie Warty. Współczesne Problemy Hydrologii VIII. 1, 1997 [In Polish].

30. KAZIMIERSKI, B., CABALSKA J., MIKOŁAJCZYK A., PILICHOWSKA-KAZIMIERSKA E. Ocena zagrożenia suszą hydrogeologiczną (gruntową) na obszarze Polski. Materiały XVIII Ogólnopolskiego. Sympozjum Zintegrowanego Monitoringu Środowiska Przyrodniczego, Szymbar, 2009 [In Polish].

31. Quarterly Bulletin of Groundwaters https://www.pgi. gov.pl/psh/psh-2/najnowsze-publikacje/5056-kwartalnybiuletyn-informacyjny-wod-podziemnych-tom-15-56-maj2017-lipiec-2017/file.html (Access on 20.10.2017)

32. Krajowy Zarząd Gospodarki Wodnej http://www.kzgw. gov.pl/index.php/pl/materialy-informacyjne/opracowanieplanow-przeciwdzialania-skutkom-suszy-na-obszarachdorzeczy (Access on 20.10.2017)

33. SZKUDLAREK Ł., STODOLAK R., KUBICZ J. Adaptacja projektu przeciwdziałania skutkom suszy do ogólnopolskich metodyk. Ekovert Łukasz Szkudlarek, 2015 [In Polish].

34. STOLARSKA M., GURWIN J.P. Wskazanie obszarów występowania zjawiska suszy wraz $\mathrm{z}$ określeniem jej zasięgu i natężenia na terenie RZGW w Warszawie oraz analiza możliwości zwiększenia na wskazanych obszarach dyspozycyjności zasobów wodnych. Wind-hydro, 2014 [In Polish].

35. GURWIN J. Long term monitoring and GIS based determination of groundwater drought propagation, the Lower Silesia region, SW Poland. Episodes 37 (3), 2014.

36. ŁABĘDZKI L., BĄK B. Predicting meteorological and agricultural drought in the system of drought monitoring in Kujawy and the upper Noteć valley. Infrastruktura $\mathrm{i}$ Ekologia Terenów Wiejskich 5/2011, 19, 2011.

37. VERMES L. How to work out a drought mitigation strategy. An ICID Guide. Guidelines for Water Management. Bonn: DVWK, 1998.

38. LLOYD-HUGHES B., SAUNDERS M.A. A drought climatology for Europe. International Journal of Climatology 22, 1571, 2002.

39. BHUIYAN C., SINGH R.P., KOGAN F.N. Monitoring drought dynamics in the Aravalli region (India) using different indices based on ground and remote sensing data, International Journal of Applied Earth Observations and Geoinformation, 8 (4), 289, 2006.

40. BLOOMFIELD J. P., MARCHANT B. P. Analysis of groundwater drought building on the standardized precipitation index approach, Hydrology and Earth System Sciences 17, 4769, 2013.

41. LI B., RODELL M. Evaluation of a model-based groundwater drought indicator in the conterminous U.S. Journal of Hydrology 526, 78, 2015.

42. SENEVIRATNES. I., NICHOLLS N., EASTERLING D., GOODESSC., KANAE S., KOSSINJ., LUO Y., MARENGO J., MCINNES K., RAHIMI M., REICHSTEIN M., SORTEBERG A., VERA C., ZHANG $\mathrm{X}$. Changes in climate extremes and their impacts on the natural physical environment, in: Managing the Risks of Extreme Events and Disasters to Advance Climate Change Adaptation. A Special Report of Working Groups I and II of the Intergovernmental Panel on Climate Change, 167, 2012.

43. KUMAR R., MUSUUZA J.L., VAN LOON A.F., TEULING A.J., BARTHEL R., TEN BROEK J., MAI J., SAMANIEGO L., ATTINGER S. Multiscale evaluation of the standardized precipitation index as a groundwater drought indicator. Hydrology and Earth System Sciences 20, 1117, 2016.

44. MOHAMMADI GHALENI M., EBRAHIMI K. Assessing impact of irrigation and drainage network on surface and groundwater resources - case study: Aaveh Plain, Iran. $21^{\text {st }}$ International Congress on Irrigation and Drainage, Tehran: ICID, 15, 2011

45. KONDRACKI J. Geografia regionalna Polski, Wydawnictwo Naukowe PWN, Warszawa, 2002 [In Polish].

46. GORACZKO M., KUBIAK-WÓJCICKA K. Komentarz do mapy hydrograficznej w skali 1:50000: arkusz N-34-97-C Bydgoszcz. Mapa Hydrograficzna Polski w skali 1:5000. Główny Geodeta Kraju, Warszawa, 2015 [In Polish].

47. SKOWRON R., PIASECKI A. Komentarz do mapy hydrograficznej w skali 1:50000: arkusz N-34-97-A Pruszcz. Mapa Hydrograficzna Polski w skali 1:5000. Główny Geodeta Kraju, Warszawa, 2015 [In Polish].

48. PACZYŃSKI B., SADURSKIA. Hydrogeologia regionalna Polski 1, Państwowy Instytut Geologiczny, Warszawa, 2007 [In Polish].

49. Modele pojęciowe i charakterystyka JCWPd. Państwowy Monitoring Środowiska, Available online http://mjwp. gios.gov.pl/modele-pojeciowe-i-charakterystyka-jcwpd/ 
modele-pojeciowe-i-charakterystyka-jcwpd.html (Access on 01.02.2017) [In Polish]

50. PEREG M. Wahania zwierciadła wód gruntowych w dolinie Dolnej Wisły. Kwartalnik Geologiczny 31 (4), 755, 1997 [In Polish].

51. DĄBROWSKI S., RYNARZEWSKI W., STRABURZYŃSKA-JANISZEWSKA R., ZACHAŚJANECKA J., PAWLAK A. The groundwater resources of hydrogeological system in the eastern Wielkopolska Lake Region. Biuletyn Państwowego Instytutu Geologicznego 445 (1), 75, 2011.

52. BĄK B., KUBIAK-WÓJCICKA. Assessment of meteorological and hydrological drought in Torun (central Poland town) in 1971-2010 based on standardized indicators. 3rd International Conference: Water resources and wetlands. 8-10 September 2016, Tulcea, Romania, 2016.

53. SHARMA T.C., PANU U.S. Prediction of hydrological drought durations based on Markov chains in the Canadian prairies. Hydrological Sciences Journal, 57 (4), 2012.

54. ŁABĘDZKI L., BĄK B. Monitoring of droughts using the standardized precipitation index SPI. Woda-ŚrodowiskoObszary Wiejskie 2 (5), 9, 2002.

55. BARKER L.J., HANNAFORD J., CHIVERTON A., SVENSSON C. From meteorological to hydrological drought using standardised indicators. Hydrology and Earth System Sciences. 20, 2483-2505, doi:10.5194/hess20-2483-2016, 2016.

56. EL AFANDI G., MORSY M., KAMEL A. Estimation of drought index over the northern coast of Egypt. IJSRSET, 2, 6, 2395, 2016.

57. HUA XIE, RINGLER C., TINGJU Zh, WAQAS A. Droughts in Pakistan: a spatiotemporal variability analysis using the Standardized Precipitation Index. Water International, 38 (5), 620, 2013.

58. LI B., RODELL M. Evaluation of a model-based groundwater drought indicator in the conterminous U.S., Journal of Hydrology 526, 78, 2015.

59. NAM W. H., HAYES M. J., SVOBODAM. D., TADESSET., WILHITE D. A., Drought hazard assessment in the context of climate change for South Korea. Agricultural Water Management 160, 2015

60. PAULO A. A., PEREIRA L.S. Drought concepts and characterization. Comparing drought indices applied at local and regional scales. Water International, 31, 1, 37, 2006.

61. STAGGE J. H., TALLAKSEN L. M., GUDMUNDSSON L., Van LOON A. F., STAHLE K. Candidate Distributions for Climatological Drought Indices (SPI and SPEI). Int. J. Climatol. 2015.
62. TOKARCZYK T., SZALIŃSKA W. Combined analysis of precipitation and water deficit for drought hazard assessment. Hydrological Sciences Journal, 59 (9), 1675, 2014.

63. ŠEBENIK U., BRILLY M., ŠRAJ M. Drought analysis using the standardized precipitation index (SPI). Acta geographica Slovenica, 57 (1), 31, 2017.

64. VIDO J. TADESSE T., ŠUSTEK Z., KANDRÍK R., HANZELOVÁ M., ŠKVARENINA J., ŠKVARENINOVÁ J., HAYES M. Drought occurrence in central European mountainous region (Tatra National Park, Slovakia) within the period 1961-2010. Hindawi Publishing Corporation, Advances in Meteorology, 5, 2015.

65. Standardized Precipitation Index User Guide. WMO, 1090, 2012.

66. OZGA-ZIELIŃSKA M., BRZEZIŃSKI J. Hydrologia stosowana [Applied Hydrology]. Wyd. Naukowe PWN, 1994 [In Polish].

67. VICENTE-SERRANO S. M., BEGUERÍA V., LORENZO-LACRUZ J., CAMARERO J. J., LÓPEZMORENO J. I., AZORIN-MOLINA C., REVUELTO J., MORÁN-TEJEDA E., SANCHEZ-LORENZO A. Performance of drought indices for ecological, agricultural, and hydrological applications. Earth Interactions, 16 (10), 1-27, 2012.

68. 68. relationship of drought frequency and duration to time scales. Eighth Conference on Applied Climatology, Anaheim, California, 1993.

69. BACHMAIR S., KOHN I., STAHL K. A quantitative analysis to objectively appraise drought indicators and model drought impacts. Hydrology and Earth System Sciences 12, 2015.

70. CHAMANPIRA GH., ZEHTABIAN GH., AHMADI H., MALEKIAN A. Effect of Drought on Groundwater Resources; a Study to Optimize Utilization Management (Case Study: Alashtar Plain). Bulletin of Environment, Pharmacology and Life Sciences 3 (10), 48, 2014.

71. KHAN S., GABRIEL H. F., RANA T. Standard precipitation index to track drought and assess impact of rainfall on water tables in irrigation areas. Irrigation and Drainage Systems, 2008.

72. CHEN Z.H., GRASBY S.E., OSADETS K.G. Predicting average annual groundwater levels from climatic variables: An empirical model. Journal of Hydrology 260, 102, 2002.

73. LEELARUBAN N., PADMANABHAN G., ODUOR P. Examining the Relationship between Drought Indices and Groundwater Levels. Water, 9 (2), 82, 2017.

74. WHITTEMORE D.O., BUTLER J.J., WILSON B.B. Assessing the major drivers of water-level declines: New insights into the future of heavily stressed aquifers. Hydrological Sciences Journal 61, 134, 2016. 
